Original Paper

\title{
Inventory Analysis of Transportation Fuel Synthesis from Woody Biomass by Large-Scale Plantation
}

\author{
Kiyotaka TAHARA*1, Yuya TSUTSUMI *2, Akihiro YAMASAKI*2, \\ Shigeo SATOKAWA $* 2$, and Toshinori KOJIMA*2 \\ (Received August 7, 2008)
}

\author{
大規模植林を想定した木質バイオマスの輸送用燃料化におけるインベントリ分析 \\ 田原聖隆*1，堤 友哉*2，山崎章弘*2，里川重夫*2，小島紀徳*2
}

\begin{abstract}
The biomass energy production by intensive cultivation is expected in future. In this study, we assumed large-scale plantation in an arid land of Western Australia. We analyzed inventory about conversion processes to various fuels from produced wood. Our evaluation indexes are calorific yield as fuel (energy in produced fuel per one ton dry-wood), $\mathrm{CO}_{2}$ emission $\left(\mathrm{CO}_{2}\right.$ emission from fuel production process per one ton dry-wood) and external energy consumption per one ton wood (primary energy basis). Calorific yield as fuel was also evaluated for the independent case where all input energy was assumed to be supplied from biomass itself or fuel from it.

From the results on energy consumption and $\mathrm{CO}_{2}$ emission analyses with external energy input, transportation of wood or fuel was found to be negligibly small in case that the conversion process was located in Australia. But in case that conversion process was located in Japan, that was considerably high (15-40\%). From the independent scenario (without energy input except that from biomass itself) analysis, in case of conversion process in Australia and transportation of produced fuel to Japan, 34\% of the energy in the whole wood (at the maximum condition of 50\% in the feedstock except felling loss) was at the maximum, expected to be recovered as energy in fuel for methanol production case. More than $30 \%$ (up to 55\%) of the energy in the wood was exhausted in the conversion process. Energy based yield of fuel and $\mathrm{CO}_{2}$ emission were much more influenced by the difference of target fuel or conversion process than the conditions of location and transportation.
\end{abstract}

\section{Key Words}

LCA, Biomass, $\mathrm{CO}_{2}$ emission, Transportation fuel

\section{1. 緒 言}

2005 年に京都議定書が発効となるなど，近年 $\mathrm{CO}_{2}$ 削減が大 きな問題となっている。また，新エネルギー国家戦略によっ て，輸送用燃料における石油依存度を現在のほぼ100\%という 状況から $80 \%$ にまで下げるという目標が設定された。このよ うな背景により, 近年バイオマスが注目されている。バイオ マスは賦存量が多く，カーボンニュートラルであるため地球 温暖化緩和に有効なエネルギー資源である。また有機物であ

* 1 National Institute of Advanced Industrial Science and Technology

16-1 Onogawa, Tsukuba-shi, Ibaraki 305-8569, Japan

* 2 Department of Materials and Life Science, Seikei University

3-3-1 Kichijojikitamachi, Musashino-shi, Tokyo 180-8633, Japan
り, 液体・気体のいずれのエネルギーにも変換が容易である ため, エネルギー多様化対策に向けた優れたエネルギー源で あると位置づけられる。特にノーブルユース（石油資源でな ければ対応しにくい用途）の一つである輸送用燃料としての 利用が考えられる。

バイオマスの高効率な利用のためには大規模エネルギープ ランテーションが有用な手法と考えられる。しかし, 日本で は土地の確保が難しいため他の対象国を探す必要がある。工

\footnotetext{
* 1 (独) 産業技術総合研究所 于 305-8569 茨城県つくば市小野川 16-1

* 2 成蹊大学理工学部物質生命理工学科 广 180-8633 東京都武蔵野市吉祥寺北町 3-3-1
} 
ネルギープランテーションは広大な土地を有する国での適用 が有効である。一方, 樹木の生育環境が良い地域では食糧生 産などの他の土地利用との競合が生じる。そこで本研究では 食料生産と競合しない西オーストラリア荒漠地での大規模植 林を想定した。植林樹種としては現地での植林実績があり，成 長速度が速い樹種であるユーカリを想定した1)。本研究では, これらを刈り取り, 集め, 輸送し様々な液体燃料化を行い, 得 られた燃料を日本に輸送するとした。

バイオマスの輸送用燃料化についてはトヨタ自動車(株) · みずほ情報総研 $\left(\right.$ 株 $^{2)}$ をはじめ多くの研究・評価が行われて いるが，いずれも各プロセスによって投入エネルギー源が異 なるため, 最終的に製造する燃料の違いなどを考慮すると, シ ナリオ間の平等な評価を行うことはできない。シナリオ間の 平等な評価を行うためには，木質自身の持つエネルギーで燃 料化及び発電を行い, プロセスで使用するシナリオ(以下, 自 立型シナリオと呼ぶ)の評価を行う必要がある。そのため, 本 研究では2.3に記述した仮定によって自立型シナリオでの評価 も行った。すなわち, バイオマスからの液体燃料への転換に あたっては，その過程で必要となるエネルギー源に，化石然 料資源由来の他エネルギーを用いる(外部エネルギー投入) シ ナリオ（以下，外部エネルギー投入シナリオと呼ぶ）と, バ イオマス起源のエネルギーのみを用いる（自立型）シナリオ での值を算出し，それぞれについての評価を行った。後者で は, 今回製造する (主として液体) 燃料が輸送用というノー ブルな 2 次エネルギーであり，またバイオマス自身は現地で は発電に用いることも出来ることから, 刈り取り, 転換, 輸 送などの過程で必要となるエネルギー源にバイオマス起源の エネルギーのみを用いるという自立型シナリオが可能となっ た。

\section{2. 方 法}

2.1 対象プロセス

本研究での評価対象とした全てのプロセスと外部エネル
ギー投入シナリオの概要は Fig. 1のようにまとめられる。本 研究では $200 \mathrm{~km} \times 200 \mathrm{~km}$ のエリアの植林を行うと仮定した。 伐採時に発生する枝・葉などの残渣を木材の 3 割 (エネルギー ベース）と仮定した。木材の平均輸送距離は $100 \mathrm{~km}$, 燃料合 成工場から主要港までの距離は上記の面積をもち年間降雨量 $200 \mathrm{~mm}$ 以下の地域から主要港までの距離である $500 \mathrm{~km}$, 海上 距離はJEMAI - LCA Pro Ver.4 (Software) 3) を利用し，オー ストラリアから日本までの平均距離である $9,000 \mathrm{~km}$ とした。 燃料流通のための日本国内輸送距離は燃料小委員会 ${ }^{4)}$ の值か ら往復 $200 \mathrm{~km}$ と仮定し，インベントリ分析を実施した。なお， 積載率は木材の場合は 0.6 , 液体燃料の場合は 0.8 と, JEMAI - LCA Pro Ver.4 (Software) ${ }^{3)}$ を利用することによってイン ベントリデータの算出を行った。また，燃料を日本国内で製 造する場合には, 木材の平均輸送距離は $600 \mathrm{~km}$ として算出を 行った。最終製造燃料はDME (ジメチルエーテル), FT 油 (フィッシャー・トロプシュ合成油), $\mathrm{MeOH}$ (メタノール), $\mathrm{EtOH}$ (エタノール) とした。それぞれのプロセスについて用 (た文献 2) 5) 11) をプロセスの特徵と併せてTable 1に示した。 また，外部エネルギー投入，自立型の両シナリオについて，(1) 廃熱利用と天日干しなどによって乾燥工程でのエネルギー消 費を抑制する，(2)廃熱利用をせず，軽油焚き乾燥機を利用し て木質チップを乾燥させる，という2つのケースを考えた。

本研究においては, 木質バイオマス中での窒素や硫黄の含 有量はわずかであるためNOx, SOxなどのその他の環境負荷物 質については配慮しなかった。また，LCI（ライフサイクルイ ンベントリ）の検討については，積み上げ法および産業連関 法の二つの方法がある ${ }^{12)}$ が, 産業連関法は検討過程が製造プ ロセスと結びつかないため, 積み上げ法と比べると理解しに くい面もあり，また現実に流通していない製品には統計資料 がないことから, 本研究では積み上げ法でLCIを検討した。本 研究で使用した換算係数及び排出源単位はTable 2 に示した。 両地域における電力についてはエネルギー・経済統計要覧 ${ }^{13)}$ の電力構成值を用い, 燃料の $\mathrm{CO}_{2}$ 排出量および低位発熱量と

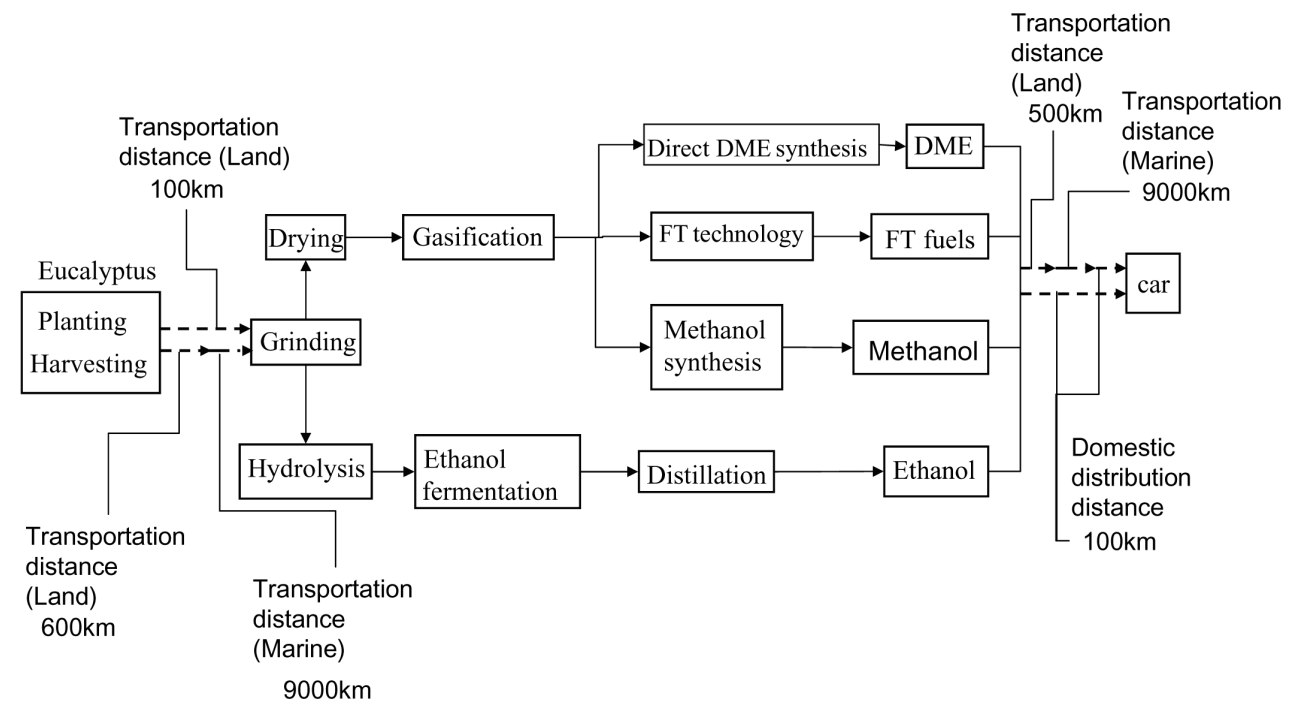

Fig. 1 Process flow diagram 
Table 1 Fuel synthesis

\begin{tabular}{|c|c|c|}
\hline Fuel & Synthesis method & Literature \\
\hline \multirow{4}{*}{ DME } & After gasification, direct synthesis without heat recovery & 5 \\
\hline & After gasification, direct synthesis with heat recovery & 6 \\
\hline & After gasification, direct synthesis $\left(\mathrm{H}_{2} / \mathrm{CO}\right.$ ratio is 1.4$)$ & 2 \\
\hline & After gasification, direct synthesis & 7 \\
\hline \multirow{5}{*}{ FT fuel } & Using woody biomass & 5 \\
\hline & $\begin{array}{l}\text { Synthesis, after treatment and compression, consumes all the excess fuel gas produced by the facility to } \\
\text { generate electric power for sale (Aspen Process) }\end{array}$ & 8 \\
\hline & Synthesis, after compression of syngas ( $\mathrm{H}_{2} / \mathrm{CO}$ ratio is 2.2 ), using woody biomass & 9 \\
\hline & After gasification, direct synthesis $\left(\mathrm{H}_{2} / \mathrm{CO}\right.$ ratio is 1.4$)$ & 2 \\
\hline & Synthesis, after compression of syngas $\left(\mathrm{H}_{2} / \mathrm{CO}\right.$ ratio is 2.2$)$ & 9 \\
\hline \multirow{6}{*}{$\mathrm{MeOH}$} & Converting a refined syngas by a gasification, not using by-product (hot water) & 5 \\
\hline & Converting a refined syngas by a gasification, using by-product (hot water) & 5 \\
\hline & $\begin{array}{l}\text { Converting a refined syngas by a gasification, considering heat recovery, the air ratio of the combustion } \\
\text { is } 1.2\end{array}$ & 10 \\
\hline & After gasification, direct synthesis $\left(\mathrm{H}_{2} / \mathrm{CO}\right.$ ratio is 1.4$)$ & 2 \\
\hline & Considering heat recovery (89.9\%) & 10 \\
\hline & Without heat recovery & 10 \\
\hline \multirow{2}{*}{$\mathrm{EtOH}$} & Fermentation, after hydrolysis with $\mathrm{H}_{2} \mathrm{SO}_{4}$ & 11 \\
\hline & Fermentation by recombinant enzyme & 11 \\
\hline
\end{tabular}

Table 2 Conversion factors and $\mathrm{CO}_{2}$ emission factors

\begin{tabular}{l|r|l}
\hline Heat & 4.18 & $\mathrm{~J} / \mathrm{cal}$ \\
\hline \multirow{2}{*}{ Electric power (Australia) } & 230.0 & $\mathrm{~g}-\mathrm{CO}_{2} / \mathrm{MJ}$ \\
\cline { 2 - 3 } & 9.97 & $\mathrm{MJ} / \mathrm{kWh}$ \\
\hline \multirow{2}{*}{ Electric power (Japan) } & 111.5 & $\mathrm{~g}-\mathrm{CO}_{2} / \mathrm{MJ}$ \\
\cline { 2 - 3 } & 8.48 & $\mathrm{MJ} / \mathrm{kWh}$ \\
\hline \multirow{2}{*}{$\mathrm{DME}$} & 66.3 & $\mathrm{~g}-\mathrm{CO}_{2} / \mathrm{MJ}$ \\
\cline { 2 - 3 } & 28.8 & $\mathrm{MJ} / \mathrm{kg}$ \\
\hline \multirow{2}{*}{ FT fuel } & 70.7 & $\mathrm{~g}-\mathrm{CO}_{2} / \mathrm{MJ}$ \\
\cline { 2 - 3 } & 44.0 & $\mathrm{MJ} / \mathrm{kg}$ \\
\hline \multirow{2}{*}{$\mathrm{MeOH}$} & 68.9 & $\mathrm{~g}-\mathrm{CO}_{2} / \mathrm{MJ}$ \\
\cline { 2 - 3 } & 19.9 & $\mathrm{MJ} / \mathrm{kg}$ \\
\hline \multirow{2}{*}{ EtOH } & 71.3 & $\mathrm{~g}-\mathrm{CO}_{2} / \mathrm{MJ}$ \\
\cline { 2 - 3 } & 26.8 & $\mathrm{MJ} / \mathrm{kg}$ \\
\hline
\end{tabular}

しては $\mathrm{JHFC}^{14)}$ の值を用いて, $\mathrm{CO}_{2}$ 排出原単位を算出した。

\section{2 外部エネルギー投入シナリオにおける評価指標}

本研究の検討項目は燃料の製造熱量および $\mathrm{CO}_{2}$ 排出量, エ ネルギー消費原単位とした。

(1) 製造燃料が有する熱量

木質バイオマス $1 \mathrm{t}$ から得られる燃料の持つエネルギー量 を算出した。

\section{(2) $\mathrm{CO}_{2}$ 排出量}

$\mathrm{CO}_{2}$ 排出量は, 植林から輸送までをも含めた全過程で外部 から投入される各エネルギー(燃料, 電力) 量に各々の $\mathrm{CO}_{2}$ 排出係数を乗じて算出した。

(3) エネルギー消費量

木質バイオマス $1 \mathrm{t}$ から製品を製造するために外部から投 入されるエネルギー（1 次エネルギー換算）を算出した。

\section{3 自立型シナリオの詳細と評価}

化石燃料を使わずにバイオマスのみですべてのプロセスに 必要とされるエネルギーをまかなったときに, バイオマスの 有するエネルギーのうち, 最終的にどれだけのエネルギーを 日本で輸送用エネルギーとして得られるのかを求めることが 目的である。転換プロセス以外のところで用いられる投入工 ネルギーは大部分が輸送用エネルギーにも転用できる液体燃 料であることから，また得られた液体燃料を輸送することは 比較的容易であることから，これらには自ら製造した液体燃 料を使用するものとした。転換プロセス内での投入エネル ギー（燃料・電力）についても木質バイオマス自身のエネル ギーを用いて代替する。自立型シナリオの例を, Fig. 2 に示 す。

Fig. 2に示したように，自立型シナリオでは燃料合成によっ

Produced fuel

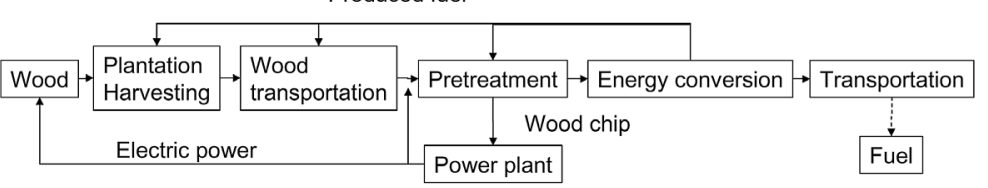

Fig. 2 Image diagram of independent scenario 
て製造する燃料やバイオマス発電によって原木自身のエネル ギーを各プロセスに投入した後に, 最終的に輸送用燃料とし て得られたエネルギーがどれだけ残るのかが算出される。ま た，バイオマス自身はカーボンニュートラルと通常考えられ ており, 全ての必要エネルギーを木質バイオマス自身のエネ ルギーでまかなう自立型シナリオでは外部からの投入エネル ギーが無く, $\mathrm{CO}_{2}$ は排出ゼロとカウントできるので, 2.2 項に おける評価指標のうち，(2)と（3）はゼロとし，(1)のみが評価 対象となる。自立型シナリオについては然料製造を豪州で 行った場合についてのみ計算した。

ここで，外部エネルギー投入シナリオで使用される軽油・重 油と, 自立型シナリオでのバイオマスから合成された液体燃 料とは, 低位発熱量ベースで換算を行った。また, バイオマ ス発電の発電効率を $20 \%$ (川崎重工 ${ }^{15)}$ の值を引用) とし, 燃 料製造プロセスに必要な電力から，使用すべき量を計算した。 なお, 外部エネルギー投入プロセスでは, LNGは発電の他, 肥 料製造過程でも利用しているが，この場合でもバイオマスと LNG の発電効率の違い (LNG を用いた時の発電効率 $52 \%$ ) を 利用して両者の換算を行った。

なお伐採時に廃棄する林地残渣（枝・葉）は発電のみには 使用できると考え, プロセス内で有効利用する場合について も検討を行ったが, その発電効率については文献 ${ }^{16)} に$ 従い, $13.3 \%$ と低い值に設定し, 評価を行った。

評価方法として，2.2(1)に示した木質バイオマス 1 tあたり の製造燃料の有するエネルギー量に加え，この值からエネル ギー収率を以下の式により求めた。

$\mathrm{E}=($ このプロセスで投入されるエネルギー)

/(木質の持つエネルギー)

\section{$2.4 \mathrm{CO}_{2}$ 削減量の評価}

自立型シナリオにおいては, バイオマスから製造した液体 燃料は $\mathrm{CO}_{2}$ 削減効果があることから, $\mathrm{CO}_{2}$ 削減量の算出を行っ た。概念を Fig. 3 に示す。(1)はバイオマスからの輸送用燃料 の製造時に排出する $\mathrm{CO}_{2}$ 排出量を示し，この負の值に(2)原油 井から軽油を製造するまでに排出する $\mathrm{CO}_{2}$ 量と(3)軽油を使用 (燃焼) する際に排出する $\mathrm{CO}_{2}$ 量を加え, 真の削減量とした。

このようにして得られた $\mathrm{CO}_{2}$ 削減量は, 外部エネルギー投 入シナリオでの $\mathrm{CO}_{2}$ 削減量とも比較を行った。

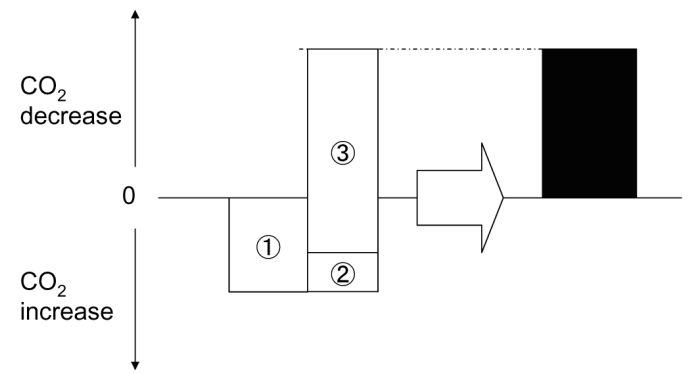

(1) : $\mathrm{CO}_{2}$ emissions from fossil fuel used for planting/ conversion process/ transportation. (Only for scenario with fossil fuel)

(2) : $\mathrm{CO}_{2}$ emissions from well to tank of fossil fuel derived light oil.

(3) : $\mathrm{CO}_{2}$ emissions by combustion of fossil fuel derived light oil equivalent.

Fig. 3 The calculation method of the $\mathrm{CO}_{2}$ reduction

\section{3. 結果および考察}

\section{1 立地条件の比較}

Fig. 4, Fig. 5 には燃料製造を国内（日本）で行う場合と現 地 (豪州) で行う場合のエネルギー消費量と $\mathrm{CO}_{2}$ 排出量のそ れぞれを比較して示した。エネルギー消費については代表的 な例としてDMEの場合のみ示したが, その他の燃料製造の場 合も同様の結果を得た。エネルギー消費において, 豪州に燃 料製造プロセスを扔いた場合では輸送の占める相対的な割合 は低いが，日本に燃料製造プロセスをおいた場合では輸送の 占める相対的な割合が大きくなることがわかる。これは最も 長距離である豪州日本間を, 豪州で然料製造を行う場合では 液体燃料を輸送するのに対し, 国内で燃料製造を行う場合で はエネルギー密度が低い固体である木材を運ぶ必要があるか らである。 $\mathrm{DME}$ のみ $\mathrm{CO}_{2}$ 排出量が現地製造の方が多くなる理 由は, 燃料製造時に現地の主に石炭を原料とする $\mathrm{CO}_{2}$ 排出原 単位が大きい電力を多く用いるためである。また，エネルギー

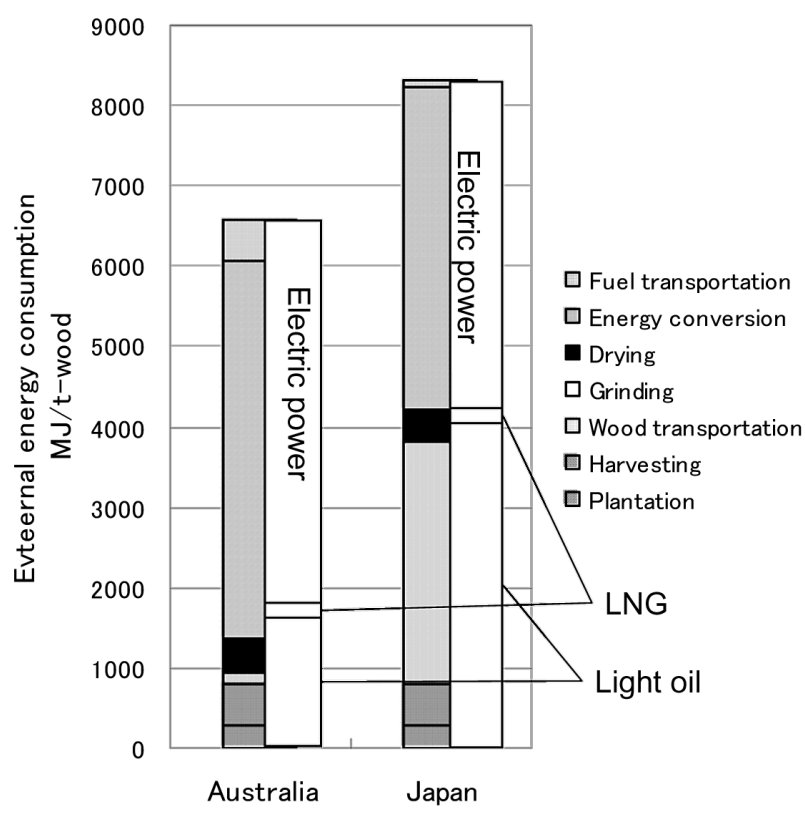

$12540 \mathrm{MJ} / \mathrm{t}$-wetwood(50\%) include felling loss

Fig. 4 Comparison of external energy consumption (primary energy basis)

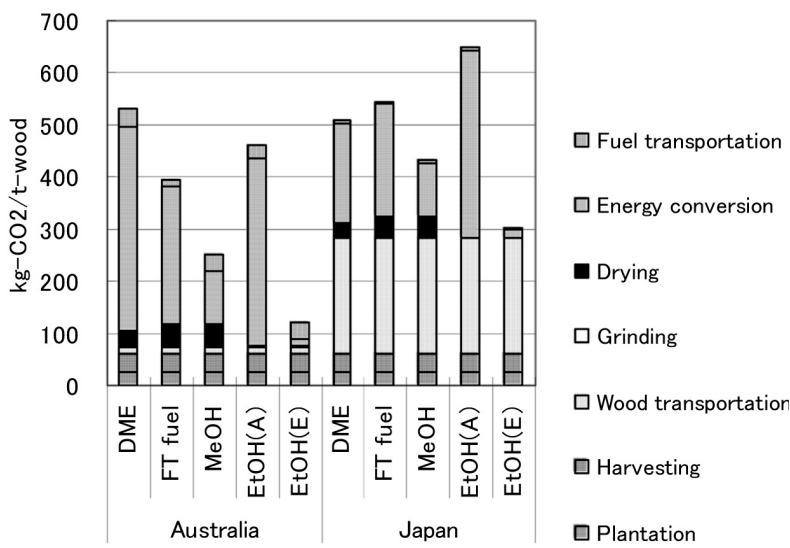

Fig. 5 Comparison of $\mathrm{CO}_{2}$ emission by external energy consumption 
消費量においても， $\mathrm{CO}_{2}$ 排出量においても，燃料製造は国内よ りも現地で行ったほうが有利であることが示された。なお，こ の評価においては，次項で示す廃熱利用は考慮しない。

\section{2 外部エネルギー投入シナリオの評価}

Fig. 6は外部エネルギー投入シナリオにおける各燃料製造時 の化石燃料消費をプロセス別・投入エネルギー別に図示した ものである。併せて各燃料のエネルギーベースでの製造量を Table 3に示す。また，プロセス毎のエネルギー投入と $\mathrm{CO}_{2}$ 排 出について, DMEの場合を Fig. 7 に示した。これらの結果よ り，単位エネルギーを有する燃料を製造するために単位エネ ルギー以上のエネルギーが投入されていることがわかる。ま た乾燥工程において多量のエネルギーを消費するため，天日 干しや廃熱を用いて乾燥工程でのエネルギー消費を抑えるこ とが有用であることがわかる。現実には，廃熱利用には困難 を伴うことが多いものの, 乾燥時のエネルギー投入量はプロ セスにより大きく左右されることから，以降の自立型シナリ オの評価と $\mathrm{CO}_{2}$ 削減量に関して両シナリオの比較を行う際に は，標準ケースとして廃熱利用を行うシナリオを用いて評価 を行った。

\section{3 自立型シナリオの評価}

投入エネルギーが想定プロセス毎にまちまちである外部エ
ネルギー投入シナリオにおいては，同一燃料を製造するプロ セスについて，3.1で示したような比較評価はある程度行える が，異なる製造燃料間についての評価を公平に行うことはで きない。そのため木質自身あるいは製造した燃料のもつエネ ルギーを外部エネルギー投入シナリオでの投入エネルギーに 代えて用いると仮定した。2.3に示した方法で算出した。また， 引用した文献では天然ガスを用いて発電を行っているため, LNGの換算についてはプロセス内で必要なLNGで発電量と同 等の電力を発生するのに必要となるバイオマス量によって相 殺した。これを基に自立型シナリオでの評価を行った結果を Fig. 8に示す。Fig. 8では各燃料製造について自立型シナリオ のプロセスごとのエネルギー消費量を図示した。どの燃料製 造においてもエネルギー消費の大半は燃料合成が占める。ま た，転換プロセスを豪州で行うとしたため，輸送の相対的な 比重は低い。炭素数が少ない燃料（メタノール・DME）では 炭素数の多い燃料（FT 油）に比べて燃料製造量（熱量換算） が多い。これはFT合成では, 多くの副生物が産出し, 触媒反 応での選択率が低いためであるとも考えられる。

\section{4 林地残材利用の評価}

Fig. 9 は，伐採時の林地残材（枝・葉）をプロセス内で発電 によって利用する場合についての評価結果を示したものであ る。Fig. 8に示した結果と比較しながら考察する。本評価では,

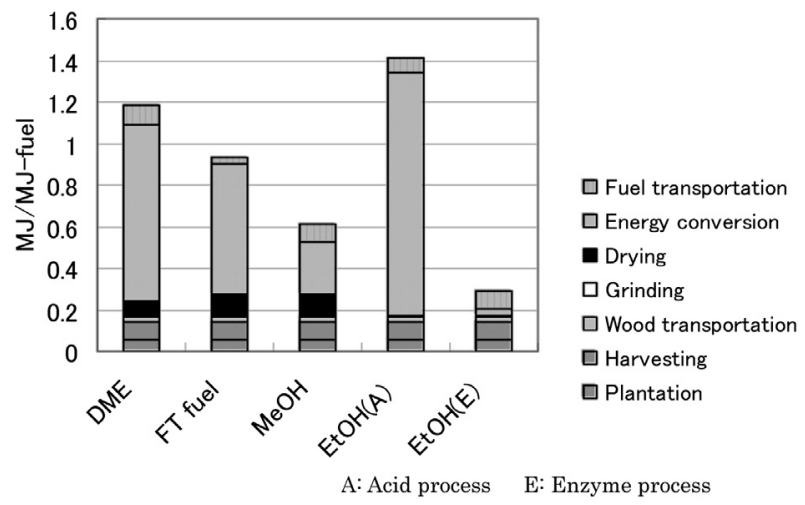

Table 3 Energy recovery as fuel

\begin{tabular}{l|c}
\hline & MJ-fuel/t-wetwood (50\%) \\
\hline DME & 5573 \\
\hline FT fuel & 3011 \\
\hline MtOH & 3859 \\
\hline EtOH(A) & 4165 \\
\hline EtOH(E) & 5103 \\
\hline
\end{tabular}

$12540 \mathrm{MJ} / \mathrm{t}$-wetwood (50\%) include felling loss

Fig. 6 Energy consumption for each conversion process

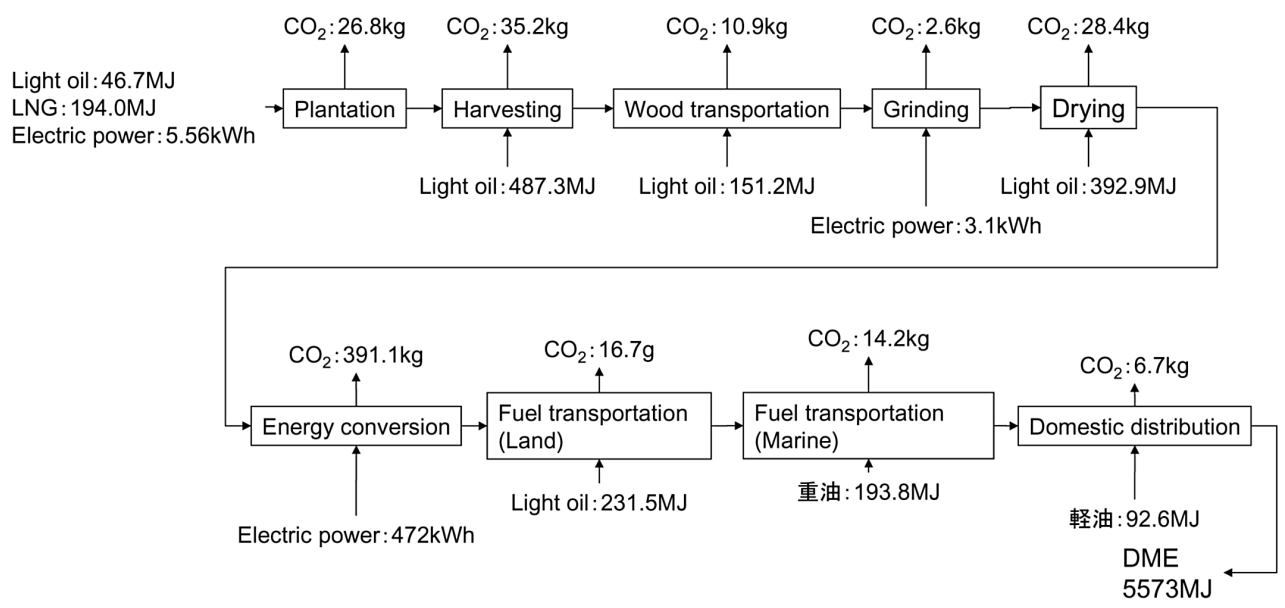

Fig. 7 Example of energy flow (DME production case) 


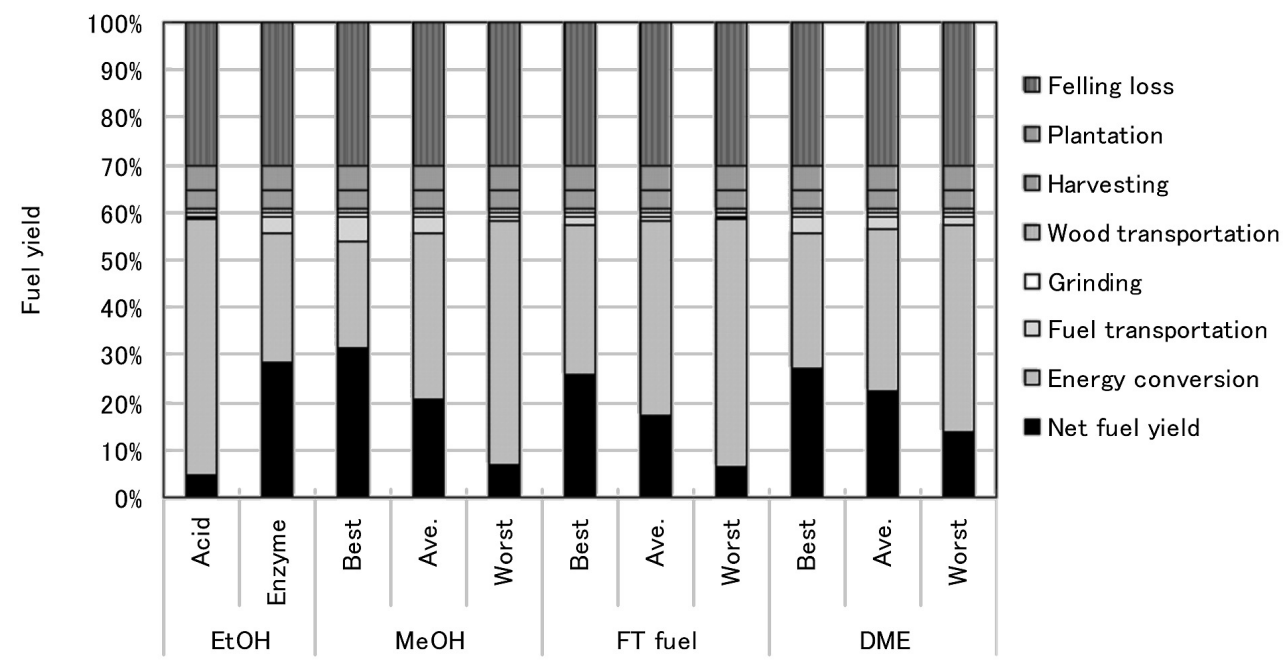

Acid: Acid process Enzyme: Enzyme process

Best: Best case Worst: Worst case Ave.: Average of data

Fig. 8 Fuel yield for each conversion process (Independent scenario without felling loss recovery)

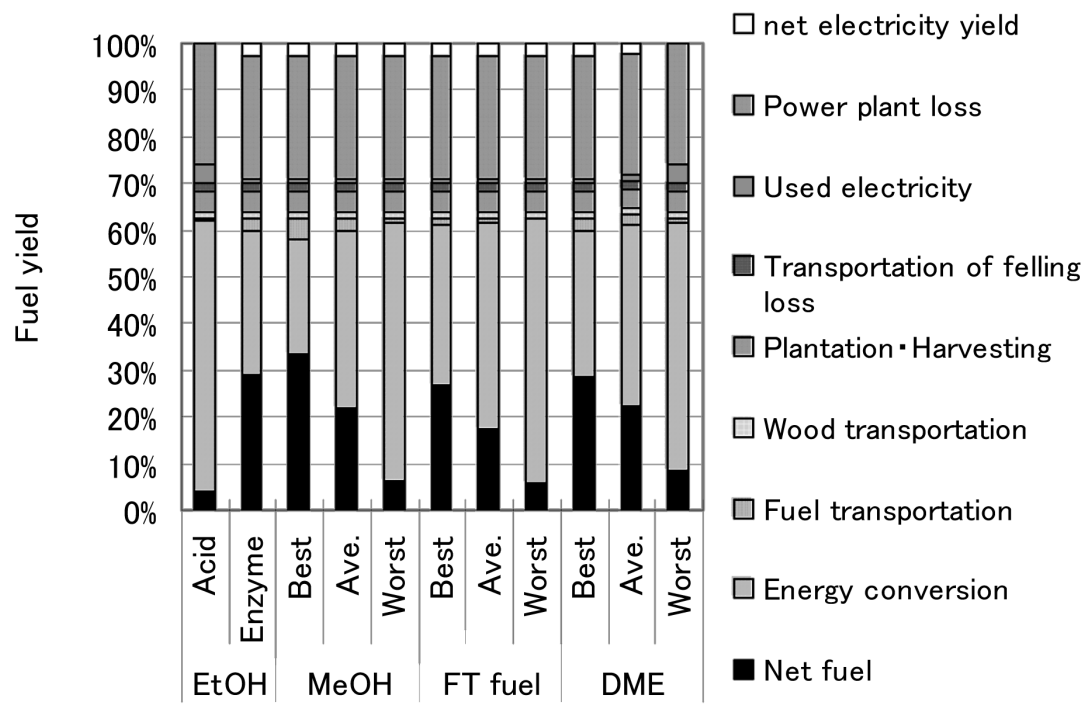

Acid: Acid process Enzyme: Enzyme process

Best: Best case Worst: Worst case Ave.: Average of data

Fig. 9 Fuel yield for each conversion process (Independent scenario with felling loss recovery)

前述のようにこれを用いた発電効率は, 本来の収穫バイオマ スである幹部の発電効率の約 $1 / 2$ として計算した結果である が，このことにより濃硫酸法によるエタノール製造の場合を 除き, 発電のために幹部を発電に使用する必要がなくなり,さ らにプロセス内で余った電力は売電できることになる。しか しながら，林地残材を利用する場合，枝や葉のかさ密度が低 いため輸送時にバイオマスから得られた輸送用然料を多量に 消費するので, 結果として林地残材利用を行ったときの燃料 製造量は林地残材を利用しない場合での燃料製造量に比べて 少なくなる場合もみられた。両者の得失は, 次項 (3.5) で考 察する。なお，林地残材をペレット化するなど前処理を行い 輸送する場合には，合成した燃料の使用量を大きく削減でき る可能性もある。

\section{$3.5 \mathrm{CO}_{2}$ 削減量}

Fig. 10 に各シナリオについて燃料毎の平均の值を使用し, $\mathrm{CO}_{2}$ 削減量の計算を行った結果を示す。外部エネルギー投入シ ナリオではメタノールと組み替え酵素でのエタノール製造以 外は $\mathrm{CO}_{2}$ 削減効果が無いことが示された。特にDMEについて は，燃料収量が多いにもかかわらず，外部エネルギー投入シ ナリオでは $\mathrm{CO}_{2}$ が増加するという結果になった。これは, 燃 料製造時に $\left(\mathrm{CO}_{2}\right.$ 排出原単位が大きい) 現地の石炭を主として 原料とする電力を多用するためであると考えられる。次に，単 位原料木質バイオマス量当たりでは，これから燃料を製造す るより発電に用いた方が $\mathrm{CO}_{2}$ 削減効果が高いことがわかる。 しかし, 電力は風力や太陽光発電などその他の再生可能エネ ルギーからも生み出すことができるため, 輸送用液体燃料が 不可欠でありかつ，これを再生可能エネルギーから製造する 


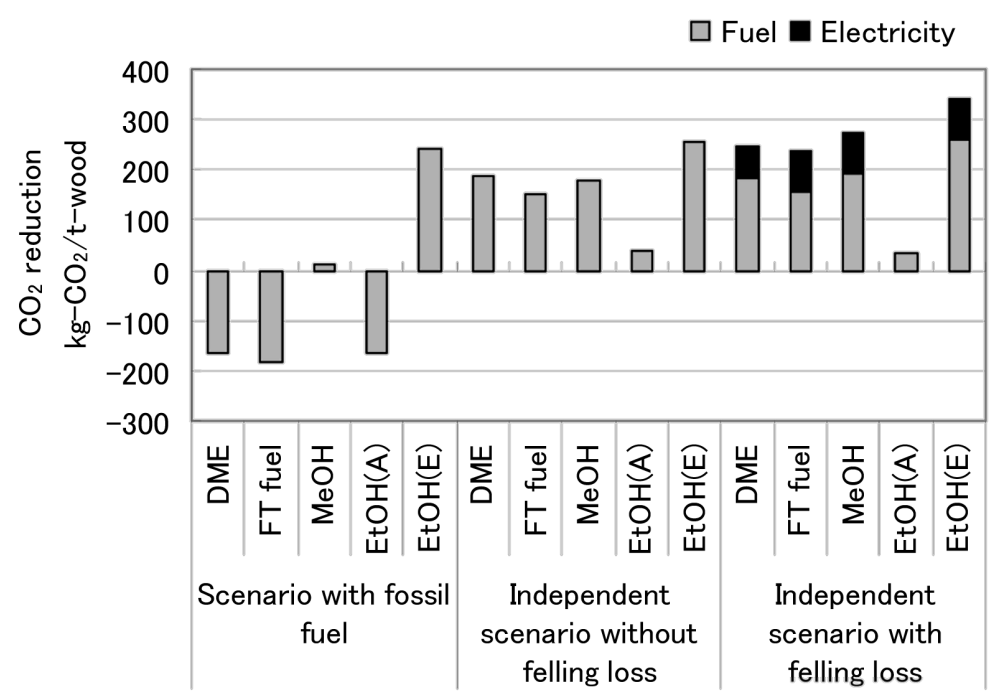

Fig. 10 Net $\mathrm{CO}_{2}$ reduction

場合にはバイオマスから製造することが妥当なシナリオとな る。また，林地残材を利用した場合は，売電可能電力分によ る $\mathrm{CO}_{2}$ 削減量が大きく，ネットでも $\mathrm{CO}_{2}$ 排出削減に寄与する 場合が多いことがわかる。ただし，エタノール(濃硫酸法)／ 自立型シナリオに抏いては林地残材を利用した場合の方が $\mathrm{CO}_{2}$ 削減量が低くなっている。

\section{4. 結 言}

海外木質バイオマスを用いて外部からのエネルギー投入を も行いながら，様々な輸送用燃料を製造し，日本で利用する ケースに対しインベントリデータを利用することにより，燃 料油収量, $\mathrm{CO}_{2}$ 排出量, エネルギー消費量に関する検討を行っ た。その結果，外部エネルギー投入量に関しても， $\mathrm{CO}_{2}$ 排出量 に関しても，DME製造の場合の $\mathrm{CO}_{2}$ 発生量を除いて燃料製造 は日本国内よりも現地豪州で行ったほうが有利であることが 示唆された。これは最も長距離である豪州日本間を，豪州で 燃料製造を行う場合では液体燃料を輸送するのに対し，国内 で然料製造を行う場合ではエネルギー密度が低い固体である 木材を運ぶ必要があるからである。 $\mathrm{DME}$ のみ $\mathrm{CO}_{2}$ 排出量が現 地製造の方が多くなる理由は，燃料製造時に現地の主に石炭 を原料とする $\mathrm{CO}_{2}$ 排出原単位が大きい電力を多く用いるため である。また，単位エネルギーを有する燃料を製造するため に単位エネルギー以上のエネルギーが投入されていることが わかった。

次いで，外部から投入していたエネルギーの全てを自らあ るいは得られた輸送用燃料を用いて代替する自立型シナリオ に対する評価から，木材の持つエネルギーのうち，林地残材 をも発電に利用しメタノール製造を行うと，最大 $34 \%$ の燃料 化が期待できることがわかった。さらに， $\mathrm{CO}_{2}$ 削減という観点 ではすべてのプロセスについて，外部エネルギー投入シナリ オより自立型シナリオの方が $\mathrm{CO}_{2}$ 削減量が増えるという結果 を得た。また，燃料の収量や $\mathrm{CO}_{2}$ 排出量は立地条件の違い以 上に，製造する燃料やプロセスの違い(林地残材の利用など) によるものが大きいということが確認された。さらに，燃料
製造時に多くのエネルギーを消費するため，今後エネルギー 変換効率が高い触媒や発酵菌の開発を含めた技術開発が望ま れる。また，林地残材を利用した場合，輸送用燃料の消費が 増えるため，燃料の収量は若干減少するが，余剩電力を売電 でき，ネットでの $\mathrm{CO}_{2}$ 削減量の増大が見込まれることがほと んどのケースで示唆された。

謝 辞

本研究の一部は三井物産環境基金の助成の下で行われた。

\section{文 献：References}

1) Kojima, T., Hamano, H., Abe, Y., Tanouchi, H., Egashira, Y., Saito, M., Law, J., Journal of Arid Land Studies, 16, 167 (2006)

2）トヨ夕自動車(株), みずほ情報総研(株), 輸送用燃料の Well-to-Wheel 評価(研究報告書), p. 45-59 (2004)：Toyota Moter Corporation, Mizuho Information \& Research Institute, Report on Yusouyounenryou no Well-to-Wheel Hyouka, p. 45-59 (2004)

3) Japan Environmental Management Association for Industry, JEMAI-LCA Pro Ver.4(Software),(2006)

4）総合資源エネルギー調査会石油分科会石油部会燃料政策小 委員会 (第 9 回)配布資料4-2 バイオマス燃料の $\mathrm{CO}_{2}$ 排出等 に関するLCA(ライフサイクルアセスメント)評価について (2) 〜我が国で想定される導入形態へのLCA適用による試 算結果，,(2003)：Sougousigen Energy tyousakai Sekiyu bunkakai Sekiyubukai Nenruouseisaku Syouiinkai (9th) material No.4-2 Baiomass nennryou no $\mathrm{CO}_{2}$ Haisyututou ni Kansuru LCA Hyouka nituite (2) - wagakuni de Soutei sareru Dounyukeitai heno LCA Tekiyou niyoru Sizankekka -,(2003)

5) Ahlvik, P., Brandbard, A., Well-to-Wheel Efficiency---For Alternative Fuels from Natural Gas or Biomass, Vagverket Publication, Borlange 2001: 85, p. 17-26(2001)

6）新エネルギー・産業技術総合開発機構，(株) ダイヤリサー チマーテック，バイオマスからのジメチルエーテル 
(DME)の生産に関する実用化可能性調査, p. 159-164

(1999) : NEDO, DRMI, Biomass karano DME no Seisan ni Kansuru Jitsuyoukanouseichousa, p. 159-164(1999)

7）堂脇清志, 江口勉, 大久保睟, 玄地裕: 電気学会論文集C 部門, 128, 168 (2008)：Dowaki, K., Eguchi, T., Okubo, R., Genchi, H., Journal of the Institute of Electrical Engineers of Japan, Part C, 128, 168-175 (2008)

8) Marano, J. J., Ciferno, J. P., Life-Cycle Greenhouse-Gas Emissions Inventory For Fischer-Tropsch Fuels, (USDOE National Energy Technology Lab.), p. 13-30 (2001)

9) 藤本真司, 隈部和弘, 福田哲久, 花岡寿明, 第一回バイオ マス科学会議発表論文集, p. 44-45(2006)：Fujimoto, S., Kumabe, K., Fukuda, T., Hanaoka, T., Minowa, T., Yabe, A., JIE, Preprint of First Biomass Science Conference, p. 44-45 (2006)

10）隈部和弘, 藤本真司, 福田哲久, 花岡寿明, 美濃輪智朗, 第一回バイオマス科学会議発表論文集, p. 138-139(2006)： Kumabe, K., Fujimoto, S., Fukuda, T., Hanaoka, T., Minowa, T., JIE, Preprint of First Biomass Science Conference, p. 138$139(2006)$

11) Kadam, K. L., Camobreco, V. J., Glazebrook, B. E., Forrest, L.
H., Jacobson, W. A., Simeroth, D. C., Blackburn, W. J., Nehoda, K. C., Environmental Life Cycle Implications of Fuel Oxygenate Production from California Biomass (USDOE, National Renewable Energy Laboratory), (1999)

12）LCA実務入門編集委員会, LCA実務入門(丸善), p. 22-40 (1998) : LCA Jitsumu Nyumon Henshuiinkai, LCA Jitsumu Nyumon(Maruzen), p. 22-40(1998)

13）日本エネルギー経済研究所計量分析部(編), エネルギー・ 経済統計要覧“06 (省エネルギーセンター), p. 217(2006)： EDMC (ed.), Energy Keizai Toukei Youran ‘06, p. 217 (2006)

14）日本自動車研究所,「JHFC総合効率検討結果」報告書, p. 2 (2006) : Japan Automobile Research Institute, JHFC Sogo Kouritsu Kentou Kekka, p. 2(2006)

15) Kawasaki Heavy Industries, Ltd., homepage(http:// www.khi.co.jp/earth/pdf/04_houkokusyo_07.pdf),(2007)

16) Larson, E. D., Consonni, S., Katofsky, R. E., Iisa, K., Frederick, Jr., W. J., A Cost-Benefit Assessment of Gasification-Based Biorefining in the Kraft Pulp and Paper Industry, Final Report, Volume.1 DE-FC26-04NT42260(USDOE), p. 14-18 (2006) 